Łukasz Wojcieszak

Politechnika Świętokrzyska

\title{
Wśród szans i barier. Aktualne problemy współpracy Unii Europejskiej z Białorusią
}

DOI: 10.19195/1643-0328.24.11

Słowa kluczowe: szansa, współpraca, UE, Białoruś

\section{Wprowadzenie}

Proces integracji Europy, łączący w ramach UE państwa znajdujące się niegdyś po obu stronach „żelaznej kurtyny”, nie objął Białorusi pozostającej od lat na uboczu wielu europejskich inicjatyw. Relacje pomiędzy Unią Europejską i Białorusią stanowią wręcz sinusoidę okresów korzystnej współpracy i jej zaprzeczenia, przybierającego niejednokrotnie postać ostentacyjnego zrywania kooperacji i zamrażania przedsięwziętych inicjatyw. Obecnie, pomimo wewnętrznych trudności Białorusi i tłumienia wybuchów społecznego niezadowolenia, wciąż wydaje się możliwe ocieplenie stosunków pomiędzy UE i Białorusią. Tym, co budzi nadzieje na możliwe zbliżanie stanowisk i zacieśnianie więzów współpracy, jest dostrzegane osłabienie relacji łączących Białoruś z Rosją.

Białoruś to państwo $\mathrm{z}$ dużą ostrożnością podchodzące do zachodnich inicjatyw mających na celu pogłębienie integracji między państwami kontynentu europejskiego. Kraj ten nie należy ani do Rady Europy, ani do WTO, natomiast istotną płaszczyzną współpracy z UE jest inicjatywa Partnerstwa Wschodniego, które obejmuje także Białoruś. Kooperacja z Unią Europejską jako całością i wieloma jej członkami z osobna (w tym z Polską) przełamuje faktyczną izolację Białorusi. Celem artykułu jest ukazanie złożonych relacji łączących Unię Europejską z Białorusią, w szczególności w aspekcie możliwej poprawy bilateralnych stosunków. Postępującą (choć nie nazbyt dynamicznie) naprawę wzajemnych relacji należy jednak widzieć w kontekście koncepcji wielowektorowości, która charakteryzuje politykę zagraniczną Białorusi.

W sytuacji widocznego osłabienia stosunków łączących Zachód z Rosją (co nastąpiło w następstwie konfliktu na Ukrainie) Unia Europejska dąży do zacieśnienia współpracy z Białorusią, co można uznać za "nowe otwarcie” we wzajemnych relacjach. W kontekście analizowanych zagadnień należy postawić hipotezę, iż aktywność UE względem 
Białorusi, pomimo jej partycypacji w Partnerstwie Wschodnim, nie przynosi sukcesów przede wszystkim ze względu na autorytaryzm białoruskich władz oraz wzrastające rosyjskie wpływy w tym państwie. Można także postawić hipotezę, że dla relacji UE-Białoruś zasadnicze znaczenie ma Rosja, $\mathrm{z}$ którą współpraca stanowi alternatywę dla „prozachodniego" kursu białoruskiego państwa.

\section{Specyfika relacji UE-Białoruś}

Kluczem do zrozumienia białoruskiej polityki zagranicznej jest wielowektorowość1. Pod pojęciem tym rozumie się utrzymanie strategicznych relacji z Rosją przy jednoczesnym zaktywizowaniu stosunków z Zachodem i innymi partnerami². Termin ten odnosi się zarazem do próby równoważenia gospodarczych wpływów Rosji. Początki realizacji tego kierunku w polityce zagranicznej Białorusi sięgają 2000 r., kiedy to w Rosji nastąpiła zmiana kierownictwa politycznego, jednak, jak zauważa Rafał Czachor, postulat polityki wielowektorowości, wiążący się z dążeniem do neutralności i politycznej równowagi pomiędzy Wschodem i Zachodem, był wysuwany przez władze w Mińsku w latach dziewięćdziesiątych XX w. Teoretyczne podstawy polityki wielowektorowości zostały po raz pierwszy przedstawione na szerszą skalę jako element kampanii prezydenckiej Aleksandra Łukaszenki w $2001 \mathrm{r}^{3}$

W początkowym okresie rządów Aleksandra Łukaszenki relacje pomiędzy Unią Europejską i Białorusią układały się poprawnie, czego wyrazem było podpisanie Umowy o partnerstwie i współpracy (PCA). Porozumienie to dawało Białorusi wiele korzyści, także o charakterze gospodarczym. Już jednak w 1996 r. relacje UE-Białoruś uległy pogorszeniu, do czego przyczyniły się niedemokratyczne działania prezydenta Łukaszenki. Reakcją UE na autorytarny kurs prezydenta Łukaszenki było między innymi zamrożenie części PCA w zakresie handlu, wstrzymanie unijnych części programów pomocy technicznej, a także zawieszenie kontaktów dwustronnych na szczeblu ministerialnym. Wprowadzono również sankcje polegające na wydawaniu zakazu wjazdu na terytorium

${ }^{1}$ Do wielowektorowości białoruskiej polityki (w bardzo ogólny sposób) nawiązuje w szczególności dokument poświęcony głównym kierunkom polityki wewnętrznej i zagranicznej tego państwa $\mathrm{z}$ listopada $2005 \mathrm{r}$. - Об утверждении Основных направлений внутренней и внешней политики Республики Беларусь, 14 ноября 2005 г. № 60-3, http://pravo.by/document/?guid=3871\&p0=H10500060 (dostęp: 23 marca 2017). $\mathrm{O}$ „wielowektorowej dyplomacji” jest również mowa w rozdz. 2 pkt. 9 prezydenckiego ukazu poświęconego koncepcji bezpieczeństwa narodowego państwa z 2010 r. -Указ Президента Республики Беларусь от 9 ноября 2010 2. N575 “Об утверждении Концепиии национальной безопасности Республики Беларусь”, Комитет государственной безопасности Республики Беларусь, http://kgb.by/ru/ukaz575 (dostęp: 29 marca 2017).

${ }^{2}$ R. Czachor, Polityka wielowektorowości Republiki Białoruś: geneza, podstawy konceptualne, przykłady realizacji, „Wrocławski Przegląd Międzynarodowy” 2011, nr 1, s. 55.

${ }^{3}$ Szerzej: R. Czachor, Polityka zagraniczna Republiki Białoruś w latach 1991-2011: studium politologiczne, Polkowice 2011, s. 165-166. 
UE wysokim rangą urzędnikom białoruskim. Istotna była też odmowa wsparcia Białorusi pomocą finansową i technologiczną ${ }^{4}$.

Białoruś dążyła do budowy Państwa Związkowego, którego powstanie poprzedziło istnienie Związku Białorusi i Rosji, dlatego też w relacjach europejskich skoncentrowana była na konsekwentnej realizacji krótkookresowych i wybiórczych zadań prowadzących do wyciągania maksymalnych korzyści z rywalizacji o względy tego państwa między Federacją Rosyjską a Unią Europejską. Białoruś wykorzystywała przy tym swoje najważniejsze atuty: niemałe zasoby gospodarcze, sieci tranzytowe, bazy militarne oraz inne zalety geopolitycznego położenia między Unią Europejską i Rosją. Ponadto Białoruś realizowała politykę zakładającą wygrywanie na braku współdziałania i spójności wśród państw członkowskich UE, których rządy i organizacje biznesu na ogół samodzielnie i bez zwracania większej uwagi na istniejące zobowiązania negocjowały na Białorusi intratne kontrakty gospodarcze ${ }^{5}$.

Dążenia prezydenta Łukaszenki, chcącego wzmocnić swoją władzę, spotkały się ze sprzeciwem UE. Proces ratyfikacji podpisanego PCA został zamrożony, zaś stosunki dwustronne na szczeblu ministerialnym uległy zawieszeniu. Białoruś była beneficjentem licznych programów Unii Europejskiej, w szczególności programu Tacis ${ }^{6}$. Na podkreślenie zasługuje rola współpracy transgranicznej - Białoruś wzięła udział w programach współpracy transgranicznej UE: „Białoruś-Litwa-Łotwa”, „Polska-Ukraina-Białoruś, „Region Morza Bałtyckiego"7. W odpowiedzi na działania białoruskich władz programy pomocy technicznej UE zostały wstrzymane (wyjątek stanowiła pomoc humanitarna, programy regionalne oraz programy mające wspierać społeczeństwo obywatelskie) ${ }^{8}$.

Władze Unii Europejskiej oczekiwały zmiany nastawienia władz Białorusi wobec opozycji. UE starała się wpływać na władze w Mińsku przed wyborami parlamentarnymi i prezydenckimi. W szczególności problemem było zapewnienie reprezentacji opozycji w komisjach wyborczych, umożliwienie sprawiedliwego dostępu do mediów państwowych dla opozycji oraz wprowadzenie regulacji wyborczych zgodnych z międzynarodowymi standardami. Brak postępu w wymienionych kwestiach uniemożliwiał jednak utrzymywanie bliższych stosunków gospodarczych i politycznych pomiędzy Białorusią i UE9.

${ }^{4}$ Ibidem, s. 144-145. Na podkreślenie zasługuje kryzys dyplomatyczny UE-Białoruś z 1998 r., który znacznie osłabił bilateralne relacje.

5 J.P. Gieorgica, Białoruś - między Polską a Rosją - konflikt czy dialog, [w:] Białoruś między Unią Europejska a Rosja, red. A. Kantorowicz, Warszawa 2012, s. 14-15.

6 Zob. C. Guicherd, The EU and Belarus: From a Zero to a Positive Sum Game, [w:] The EU \& Belarus: between Moscow \& Brussels, red. A. Lewis, London 2002, s. 319.

7 А. Русакович, Беларусь - Европейский союз: основные проблемы партнерства, [w:] Актуальныья пытанні беларуска-польскіх адносін: да 20-годдзя Дагавора паміж Рэспублікай Беларусь і Рэспублікай Польшча аб добрасуседстве, сяброўстве і супрацоўніцтве ад 23 чэрвеня 1992 г. : матэрыялы беларус.пол. круглага стала, red. В.Г. Шадурскі, Мінск 2012, s. 85.

8 A. Zagorski, EU Policies Towards Russia, Ukraine, Moldova and Belarus, „Occasional Paper Series” 2005, nr 35, s. 11, https://www.files.ethz.ch/isn/10671/doc_10702_290_en.pdf (dostęp: 14 lutego 2017).

${ }^{9}$ Ibidem, s. 12. 
Realizację Europejskiej Polityki Sąsiedztwa, przejawiającą się w szczególności wsparciem Unii Europejskiej dla budowy ustroju demokratycznego w państwach położonych pomiędzy UE i Rosją, ta ostatnia interpretowała jako działania skierowane przeciwko niej. Doprowadziło to do pogorszenia wzajemnych relacji, na co dodatkowy wpływ miały istniejące stereotypy i uprzedzenia, brak zaufania, a także różne zrozumienie takich pojęć, jak: demokracja, wolność czy prawa człowieka. Pojęcia te inaczej rozumiane są zarówno w Rosji, jak i na Białorusi ${ }^{10}$.

Chociaż regulacje obowiązujące na rynku unijnym utrudniały konkurencyjność państwom niebędącym członkami UE, to cena towarów białoruskich: produktów ropopochodnych, wyrobów przemysłu chemicznego, tekstyliów czy przyrządów optycznych, była na tyle atrakcyjna, że znajdowały one nabywców na obszarze Unii Europejskiej. Na początku XXI w. stale wzrastała wartość inwestycji państw UE na Białorusi, przy czym liderami były Niemcy i Holandia, skąd pochodziło blisko $30 \%$ inwestycji zagranicznych ${ }^{11}$.

Od 2004 r. zarówno Białoruś, jak i Unia Europejska deklarowały wolę rozwijania współpracy ${ }^{12}$. Pomimo braku znaczących postępów w demokratyzacji życia politycznego w państwie Unia Europejska łagodziła swoją politykę wobec Białorusi. Prezydent Łukaszenka, zdając sobie sprawę z położenia swojego państwa, starał się to wykorzystać w stosunkach zarówno z UE, jak i z Rosją ${ }^{13}$. W 2004 r. w następstwie budzącego liczne wątpliwości referendum, które otwierało drogę do trzeciej kadencji prezydenta Łukaszenki, Unia Europejska nałożyła sankcje na przedstawicieli władz Białorusi. Sankcjami tymi objęto łącznie, do 2006 r., kilkudziesięciu przedstawicieli reżimu. Obejmowały one zakaz wjazdu na terytorium UE oraz zamrożenie białoruskich aktywów finansowych w państwach Unii. Białoruś została również wykluczona $\mathrm{z}$ grupy państw korzystających $\mathrm{w}$ handlu z UE $\mathrm{z}$ uprzywilejowanych taryf celnych ${ }^{14}$. Już jednak w październiku 2007 r. prezydent Łukaszenka podpisał zgodę na otwarcie w Mińsku przedstawicielstwa Komisji Europejskiej, co stanowiło istotne wydarzenie w relacjach UE-Białoruśs ${ }^{15}$.

10 J.M. Fiszer, Białoruś między Rosją i Unią Europejska — konflikty interesów i perspektywy współpracy, [w:] Białoruś między..., s. 20.

11 E. Mironowicz, Unia Europejska w polityce białoruskiej 2008-2010, [w:] Białoruś między..., s. 84-85, cyt. za: В. Улахович, Формирование основ внешней политики Республики Беларусь, Минск 2009, s. 182.

12 E. Mironowicz, op. cit., s. 85.

${ }^{13}$ K. Iwańczuk, Pozycja geopolityczna Białorusi, [w:] Białoruś w stosunkach międzynarodowych, red. I. Topolski, Lublin 2009, s. 133.

${ }^{14}$ R. Zięba, Główne kierunki polityki zagranicznej Polski po zimnej wojnie, Warszawa 2010, s. 237. W 2005 r. doszło do sporu pomiędzy białoruskimi władzami a polską mniejszością, co na pewien czas bardzo negatywnie wpłynęło na relacje Polski z Białorusią.

${ }^{15}$ K. Młynarska, K. Pałka, Białoruś - między Rosja a Europą. Kierunki polityki zagranicznej Białorusi w okresie prezydentury Aleksandra Łukaszenki, [w:] Wschód i Zachód w wymiarze globalnym. Doświadczenia z przeszłości a perspektywy na przyszłość, red. M. Miłek, G. Wilk-Jakubowski, R.S. Brzoza, Kielce 2012, s. 38. W lutym 2008 r. prezydent Łukaszenka oświadczył: „Przyznaję, że błędem i brakiem w naszej polityce zagranicznej była jej jednokierunkowość nastawiona na Rosję. Faktycznie straciliśmy Zachód. Staliśmy na jednej nodze, a powinniśmy stać na dwóch. Znajdujemy się między Zachodem i Rosją. Jesteśmy mostem między Rosją i Zachodem". Wywiad Aleksandra Łukaszenki dla Reuters News Agency, 15 lutego 2008, cyt. za: M. Mączka, Geopolityka i geostrategia Białorusi w świecie - jak widzi i kształtuje ją Mińsk?, [w:] Białoruś - terra incognita. Materiały z konferencji, red. M. Smoleń, Kraków 2010, s. 45. 
Po wyborach parlamentarnych na Białorusi we wrześniu 2008 r., które zostały uznane przez OBWE za bardziej demokratyczne niż poprzednie, rozpoczęła się odwilż w stosunkach między państwami zachodnimi a Białorusią. Unia Europejska zniosła sankcje wobec przedstawicieli białoruskich władz. W październiku 2008 r. doszło do spotkania wysokiego przedstawiciela Unii do spraw zagranicznych i polityki bezpieczeństwa oraz Trójki UE z szefem MSZ Białorusi w Luksemburgu. Wkrótce potem miała miejsce wizyta delegacji Komisji Europejskiej na Białorusi, podczas której rozmawiano o perspektywach dalszego współdziałania na linii Mińsk-Bruksela. Co ważne, równolegle z dialogiem UE-Białoruś toczył się dialog polsko-białoruski ${ }^{16}$. Pomimo rozwoju relacji stosunki pomiędzy UE i Białorusią radykalnie pogorszyły się wskutek represji zastosowanych przez reżim wobec opozycji po wyborach prezydenckich w grudniu $2010 \mathrm{r}$.

\section{Aktywność w ramach Partnerstwa Wschodniego}

Partnerstwo Wschodnie jest inicjatywą Polski i Szwecji. Program Partnerstwa Wschodniego to polityka zagraniczna Unii Europejskiej, która jest realizowana w ramach Europejskiej Polityki Sąsiedztwa. Inicjatywa ta, skierowana do sześciu państw Europy Wschodniej: Armenii, Azerbejdżanu, Białorusi, Gruzji, Mołdawii oraz Ukrainy, ma na celu zbliżanie tych państw do Unii Europejskiej poprzez pogłębioną współpracę oraz działania integracyjne w oparciu o unijne wartości, normy i standardy. Partnerstwo Wschodnie ma na celu wspieranie reform służących instytucjonalnemu wzmocnieniu i modernizacji państw partnerskich dla dobra ich obywateli ${ }^{17}$.

Współpraca ma przebiegać na różnych płaszczyznach - związanych z migracją (tu istotne jest wprowadzenie ruchu bezwizowego), utworzeniem strefy wolnego handlu, a także pogłębieniem kooperacji w płaszczyźnie społecznej (tu istotne byłoby promowanie współdziałania między partnerami społecznymi na poziomie lokalnym i regionalnym czy wspieranie budowy społeczeństwa obywatelskiego). Państwa objęte programem powinny dostosowywać ustawodawstwo i normy do standardów UE ${ }^{18}$. Szczególnie istotna jest w tej inicjatywie rola Polski od lat prowadzącej wobec swojego sąsiada politykę dużo bardziej niekonfliktową niż władze UE.

Początkowo nie było pewne, czy Białoruś zostanie objęta programem Partnerstwa Wschodniego. W marcu 2009 r. na szczycie Rady Europejskiej została jednak podjęta decyzja o włączeniu Białorusi do Partnerstwa Wschodniego Unii Europejskiej. W ramach dialogu prowadzonego z UE władze Białorusi zdecydowały się na reformę prawa wyborczego; intensyfikacji uległy też relacje między UE i Białorusią ${ }^{19}$. Choć wprowa-

16 R. Zięba, op. cit., s. 240-241.

17 Partnerstwo Wschodnie, Ministerstwo Spraw Zagranicznych, http://www.msz.gov.pl/pl/polityka_zagraniczna/partnerstwo_wschodnie (dostęp: 13 lutego 2017).

18 A. Dudek, Koncepcje polskiej polityki wschodniej po rozszerzeniu Unii Europejskiej, [w:] Rosja między imperium a mocarstwem kolonialnym, red. A. Dudek, R. Mazur, Toruń 2010, s. 281-282.

19 W latach 2009-2010 dała się zauważyć duża aktywność dyplomatyczna zarówno przedstawicieli Białorusi, jak i członków UE. В.Е. Снапковский, История внешней политики Беларуси: пособие [для 
dzone zmiany obejmowały wiele kwestii, to nie reformowały sposobu przeprowadzania wyborów w istotny sposób. Wybory prezydenckie z 2010 r. spotkały się jednak z krytyką władz UE. Represje zastosowane wobec opozycyjnych kandydatów na prezydenta pociągnęły za sobą wznowienie i rozszerzenie sankcji wizowych wobec przedstawicieli Białorusi. Objęły one ponad 150 osób, które UE uznała za odpowiedzialne za sfałszowane wybory i zastosowane represje $\mathrm{e}^{20}$.

Za sprawą Partnerstwa Wschodniego Unia Europejska mogłaby skutecznie wspierać Białoruś, koncentrując się na bardziej konkretnej i skutecznej polityce. Istotne mogłoby okazać się w szczególności wzmocnienie flagowej inicjatywy Partnerstwa, jaką jest wsparcie małych i średnich przedsiębiorstw. Jak zauważył J. Fiszer, możliwe byłoby oferowanie im pomocy prawnej oraz kredytów na rozpoczęcie prowadzenia działalności gospodarczej. Rozwój sektora małych i średnich przedsiębiorstw znalazłby bezpośrednie przełożenie na poprawę sytuacji społeczeństwa obywatelskiego ${ }^{21}$. Byłoby to działanie konkurencyjne wobec wsparcia płynącego ze strony Rosji. Dla rozwoju relacji UE-Białoruś znaczenie miały kolejne szczyty Partnerstwa Wschodniego - przede wszystkim w 2011 r. w Warszawie, ale także w 2013 r. w Wilnie i w 2015 r. w Rydze.

W kontekście funkcjonowania Partnerstwa Wschodniego istotne jest spotkanie szefa polskiej dyplomacji Witolda Waszczykowskiego z wiceminister spraw zagranicznych Białorusi Aleną Kupczyną w lipcu 2016 r. Głównymi tematami rozmów były kwestie dwustronne, sytuacja mniejszości polskiej na Białorusi oraz bezpieczeństwo regionalne. Zdaniem polskiego ministra postępująca normalizacja relacji pomiędzy Polską i Białorusią oznacza postęp we wszystkich sferach współpracy nie tylko w obszarze kontaktów politycznych i parlamentarnych ${ }^{22}$. Należy także wspomnieć o bardzo ważnej wizycie, jaką w październiku 2016 r. złożył na Białorusi wicepremier Mateusz Morawiecki. Była ona szczególnie istotna $\mathrm{z}$ uwagi na postępujące zacieśnianie współpracy gospodarczej ${ }^{23}$ pomiędzy Białorusią i Polską.

студентов по специальностям "Международные отночения», “Лингвострановедение», "Международная журналистика], Минск 2013, s. 235.

${ }^{20}$ K. Młynarska, K. Pałka, op. cit., s. 39-40.

${ }^{21}$ J.M. Fiszer, op. cit., s. 36-37.

22 Polsko-białoruskie rozmowy w Warszawie, Ministerstwo Spraw Zagranicznych, 19 lipca 2016, http:// www.msz.gov.pl/pl/polityka_zagraniczna/partnerstwo_wschodnie/polsko_bialoruskie_rozmowy_w_warszawie_pw;jsessionid=1679F7E53E66EBF2AA7383F2D030EB07.cmsap2p (dostęp: 13 lutego 2017). Minister Witold Waszczykowski podkreślił, że dowodem na ocieplenie wzajemnych stosunków jest wzmocnienie dialogu sektorowego. Warto wspomnieć także o dwustronnych konsultacjach politycznych, poświęconych przede wszystkim uporządkowaniu bazy traktatowej oraz relacjom dwustronnym - w tym stosunkom gospodarczym i kwestiom mniejszości narodowych w Polsce i na Białorusi. Strony omówiły ponadto kwestie stosunków pomiędzy Białorusią a Unią Europejską, również w kontekście toczących się prac dotyczących reformy Europejskiej Polityki Sąsiedztwa. Poruszony został także temat oczekiwań Białorusi wobec Partnerstwa Wschodniego, a także kwestia bezpieczeństwa regionalnego. Spotkanie zakończyło podpisanie „Porozumienia między Rządem Rzeczypospolitej Polskiej a Rządem Republiki Białorusi o współpracy w dziedzinie edukacji”, regulującego między innymi zasady kierowania na Białoruś nauczycieli języka polskiego oraz prowadzenia wymian naukowych i studenckich. Ibidem.

${ }^{23}$ Według wicepremiera Morawieckiego polscy przedsiębiorcy będą mogli wziąć udział w procesach prywatyzacyjnych na Białorusi. Wicepremier Morawiecki: zostaliśmy zaproszeni do udziału w prywatyzacji na Bia- 


\section{Szansa na naprawę relacji}

Po brutalnym stłumieniu demonstracji opozycji w grudniu 2010 r. stosunki pomiędzy Unią Europejską i Białorusią uległy poważnemu pogorszeniu. Prezydent Łukaszenka po raz kolejny dokonał politycznej wolty, zacieśniając kooperację z Rosją. Odczuwalna ekonomiczna słabość Rosji, będąca wynikiem zarówno spadku cen ropy, jak i sankcji wprowadzonych $\mathrm{w}$ następstwie konfliktu na Ukrainie, przesądziła jednak o kolejnym zwrocie Białorusi w kierunku UE. Polityczne manewry dokonywane przez prezydenta Łukaszenkę świadczą o znaczeniu Białorusi, która z racji swojego położenia mogłaby odgrywać rolę pomostu między Unią Europejską i Rosją.

Należy stwierdzić, że Zachód oczekuje od Białorusi politycznej liberalizacji reżimu, a co za tym idzie - prawdziwie demokratycznych wyborów, zaprzestania polityki naruszania praw człowieka oraz wypuszczenia na wolność więźniów politycznych, co warunkuje podjęcie dialogu politycznego i udzielanie dalszej pomocy kredytowej. Zachód oczekuje również intensyfikacji procesów prywatyzacji, której efektem ma być strukturalna utrata kontroli państwa nad newralgiczną infrastrukturą ekonomiczną i osłabienie procesu wykupu najlepszych przedsiębiorstw przez firmy z Rosji. Odpowiedzią Unii Europejskiej na niechęć Białorusi do wprowadzania pożądanych reform było natomiast wprowadzenie:

- ograniczeń wjazdowych do UE i zamrożenie kont niektórym czołowym przedstawicielom białoruskiego reżimu,

- embargo na sprzedaż broni oraz materiałów mogących służyć represjom,

- sankcji gospodarczych i finansowych wobec przedsiębiorstw zaplecza finansowego reżimu ${ }^{24}$.

Wybuch konfliktu na Ukrainie na powrót spowodował zmianę stanowiska władz Unii Europejskiej. Spodziewano się, że izolowana i słabnąca Rosja przestanie być atrakcyjnym partnerem dla władz w Mińsku. UE postanowiła znieść sankcje wobec obywateli Białorusi (w tym prezydenta Łukaszenki), choć istotnym problemem pozostało uproszczenie reżimu wizowego między UE i Białorusią ${ }^{25}$. Jak uważa szefowa przedstawicielstwa UE na Białorusi, Andrea Wiktorin, Unia Europejska chciałaby podpisać dwustronną umowę o współ-

łorusi, Polskieradio.pl, 24 października 2016 r., http://www.polskieradio.pl/75/921/Artykul/1684439,Wicepremier-Morawiecki-zostalismy-zaproszeni-do-udzialu-w-prywatyzacji-na-Bialorusi (dostęp: 27 lutego 2017).

${ }^{24}$ J.P. Gieorgica, op. cit., s. 16-17.

${ }^{25}$ Jednym z warunków uproszczenia reżimu wizowego między Unią Europejską i Białorusią jest uregulowanie kwestii nielegalnej migracji. Główną przeszkodą w osiągnięciu porozumienia jest umowa dotycząca readmisji, a więc odsyłania nielegalnych migrantów do państwa, $\mathrm{z}$ którego przybyli ( $\mathrm{w}$ tym przypadku z UE na Białoruś). Umowa o readmisji jest standardową procedurą i warunkiem liberalizacji przepisów wizowych dla państw spoza UE. Co więcej, Białoruś ma otrzymać finansowe wsparcie w celu rozwiązania problemów wynikających z rosnącej liczby nielegalnych imigrantów (dotyczyłoby to osób zatrzymanych na jej terytorium). Unijne finansowanie, które zostanie przekazane w ramach Europejskiego Instrumentu Sąsiedztwa i Partnerstwa, ma być przeznaczone na utworzenie ośrodków tymczasowego pobytu dla nielegalnych migrantów. Białoruś: Mińsk otrzyma od UE 7 mln euro na nielegalnych migrantów, „Rzeczpospolita”, 17 stycznia 2017 r., http://www.rp.pl/Uchodzcy/170119149-Bialorus-Minsk-otrzyma-od-UE-7-mln-eurona-nielegalnych-migrantow.html\#ap-1 (dostęp: 25 lutego 2017). 
pracy z Białorusią. Warunkiem jest jednak zniesienie kary śmierci (Białoruś jest jedynym państwem w Europie, w którym kara ta jest wykonywana) ${ }^{26}$. Brak znaczących postępów $\mathrm{w}$ dziedzinie ochrony praw człowieka i przestrzegania zasad demokracji jest zresztą od lat jednym z kluczowych problemów na drodze do porozumienia Białorusi z UE.

Unia Europejska, pomimo wielu prób, nie znalazła skutecznego środka oddziaływania na Białoruś. Rezygnując z ratyfikowania umowy z Białorusią, UE wprowadzała za to kolejne sankcje, co ograniczało jej oczekiwania wobec możliwości wywierania wpływu na sytuację w tym państwie ${ }^{27}$. Stłumienie społecznych protestów w marcu $2017 \mathrm{r}$. i zastosowane przez reżim represje również mogą spowodować zmianę nastawienia UE wobec Białorusi w postaci kolejnych sankcji, co znów oddali perspektywę współpracy (zwłaszcza w sferze gospodarczej). Dotychczasowe działania UE (czy też - w szerszym rozumieniu - Zachodu) spowodowały zacieśnianie się współpracy Białorusi z Rosją, lecz także, co ciekawe, z innymi państwami (jak Iran czy Wenezuela) postrzeganymi jako nieprzychylne Zachodowi.

Zdecydowane tłumienie przez białoruskie władze protestów jej przeciwników i ciągle powtarzane, lecz bezskuteczne nawoływania o zwiększenie demokratyzacji odsuwają na dalszy plan inne, długoterminowe cele UE, jakimi pozostają aktywność Białorusi w Partnerstwie Wschodnim oraz realizacja konkretnych projektów regionalnych ${ }^{28}$. Aktualność zachowuje opinia Adama Eberhardta z połowy pierwszej dekady, iż ponawiające się kryzysy $\mathrm{w}$ stosunkach państw zachodnich $\mathrm{z}$ Białorusią oraz dalsze negatywne tendencje w rozwoju sytuacji wewnętrznej w tym państwie wykazały nieefektywność dotychczasowej polityki izolacji. Dlatego też korzystniejsze byłoby stopniowe angażowanie Białorusi we współpracę ${ }^{29}$ nawet mimo problemów wynikających z niedemokratycznego kursu władz tego państwa. Pewnym wyzwaniem jest więc kontynuacja dialogu z Białorusią po stłumieniu społecznych wystąpień w marcu $2017 \mathrm{r}$.

Otwarcie Białorusi na Zachód blokuje głównie zależność jej gospodarki od gospodarki rosyjskiej. To, czy inwestycje zachodnich (w tym i polskich) przedsiębiorców mogą wpłynąć na jej uniezależnienie się od Rosji, jest jednak zależne od wielu czynników. Zasadnicze znaczenie ma ugruntowanie współpracy z Białorusią i inspirowanie jej rozwoju, który jednak nie szkodziłby stosunkom rosyjsko-białoruskim. W relacjach z Białorusią kluczową rolę powinna zatem odegrać współpraca o charakterze gospodar$\mathrm{czym}^{30}$. Polskie władze kładą akcent na ten właśnie aspekt kooperacji ze swoim wschodnim sąsiadem, czego dowodem jest chociażby wizyta ministra Mateusza Morawieckiego

${ }^{26}$ UE chce podpisać stowarzyszenie z Białorusią, Sputniknews.com, 28 listopada 2016 r., https://pl.sputniknews.com/polityka/201611284308704-ue-bialorus-porozumienie (dostęp: 14 lutego 2017).

27 J.P. Gieorgica, op. cit., s. 17.

28 B.Е. Снапковский, op. cit., s. 235.

29 A. Eberhardt, Republika Białoruś a wspótpraca i integracja w Europie - przyczyny i konsekwencje izolacji międzynarodowej, [w:] Polska i Białoruś po rozszerzeniu Unii Europejskiej, red. M. Krzysztofowicz, Warszawa 2005, s. 16.

${ }^{30}$ Jak rozmawiać z Białorusią? Prof. Kazimierz Kik dla Fronda.pl, Fronda.pl, 5 listopada 2016 r., http:// www.fronda.pl/a/jak-rozmawiac-z-bialorusia-prof-kazimierz-kik-dla-frondapl,81283.html (dostęp: 5 listopada 2016). 
na Białorusi w październiku 2016 r. Na podkreślenie zasługuje rozwój relacji między regionami Polski i Białorusi zwłaszcza w wymiarze gospodarczym.

Unia Europejska jest zainteresowana współpracą z Białorusią w zakresie zapewnienia regionalnego i subregionalnego bezpieczeństwa (a także przeciwdziałania zagrożeniom transgranicznym), ochrony środowiska oraz transportu. Białoruś jest też barierą napływu nielegalnych imigrantów i działalności przestępczej (jak np. handel narkotykami) ${ }^{31}$. Na uwagę zasługuje dialog techniczny prowadzony między UE a Białorusią w dziedzinach takich, jak między innymi energia, środowisko naturalne, sprawy celne czy transport $^{32}$. Ponadto dla UE ważne jest doprowadzenie na Białorusi do demokratycznych przemian i zwiększenia swobód obywatelskich, co nabiera szczególnego znaczenia w konsekwencji każdego znaczącego przejawu „twardego kursu” okazanego przez władze przeciwnikom prowadzonej przez władze polityki.

Zasadnicze znaczenie dla Białorusi, zwłaszcza w aspekcie trwającego tam kryzysu, ma sfera gospodarcza, a więc w szczególności rozwój handlu, możliwość dostępu do wewnętrznego rynku, polepszania warunków inwestycyjnych oraz ram regulacyjnych, a nawet możliwość transformacji gospodarczej. Potencjalne przemiany gospodarcze mogłyby stanowić uzupełnienie pomocy technicznej i współpracy ważnych w takich obszarach, jak energetyka, ochrona środowiska czy problemy związane $\mathrm{z}$ wymiarem sprawiedliwości i sprawami wewnętrznymi ${ }^{33}$. W dalszej perspektywie postępującej kooperacji z Białorusią możliwe byłoby podpisanie umowy o wolnym handlu z UE. Takie porozumienie wymaga jednak członkostwa Białorusi w WTO, a zatem realizacji wielu reform gospodarczych. Ponadto wymagałoby to także zmiany umowy unii celnej z Ro$\mathrm{sją}^{34}$, co w praktyce jest trudne do realizacji.

\section{Rola relacji Białorusi z Rosją}

Białoruś połączona jest $\mathrm{z}$ Rosją silnymi więzami, co stanowi wyjątek w relacjach FR z państwami będącymi byłymi republikami związkowymi ZSRR. Białoruś wcześnie przystąpiła do WNP, była członkiem-założycielem unii ekonomicznej z Rosją i Ukrainą powołanej w 1993 r., zgodziła się na unię monetarną z Rosją, przekazała jej swoją broń nuklearną i zgodziła się na stacjonowanie wojsk rosyjskich na swoim terytorium. Jak stwierdził S. Huntington, „w 1995 roku, jeśli nie liczyć nazwy, była praktycznie częścią

31 В. Силицкий, Беларусь в международном контексте, [w:] Беларусь и Европейский союз: от изоляции к сотрудничеству, red. Х.-Г. Вик, Ш. Малериус, Вильнюс 2011, s. 17.

32 К.-О. Ланг, М. Коопманн, ЕС и Беларусь: отношения с резервными возможностями, [w:] Беларусь и Европейский союз..., s. 33.

33 Ibidem, s. 38.

34 А. Чубрик, Текущее положение дел и перспективы сотрудничествас ЕС: соииально-экономический и инфраструктурный аспекты, [w:] Беларусь и Европейский союз..., s. 154. Warto zauważyć, że Białoruś, wraz z Rosją, Kazachstanem, Armenią i Kirgistanem tworzy Euroazjatycką Unię Gospodarczą, która zakłada współpracę szerszą niż ta w ramach unii celnej. 
Rosji”35, choć w następnych latach integracja została sformalizowana, w efekcie czego powstało państwo związkowe łączące Białoruś i Rosję.

Władze Rosji uważają, że obszar Europy Wschodniej, w tym także Białoruś, powinien pozostać w wyłącznej strefie wpływów FR i z niechęcią przypatrują się inicjatywom UE tworzonym w ramach Wymiaru Wschodniego, a zwłaszcza Europejskiej Polityki Sąsiedztwa $^{36}$. Zdaniem Adama Eberhardta „uzależnianie pomocy gospodarczej Rosji dla Białorusi od faktycznych ustępstw jej władz w sprawach istotnych dla Moskwy stało się trwałym elementem polityki prezydenta Putina"37. Białoruś przez lata była uważana za sojuszniczkę Rosji ${ }^{38}$, co wyróżniało ją na tle innych byłych republik związkowych ZSRR, nierzadko podatnych na „kolorowe rewolucje” (tzw. rewolucja dżinsowa z marca $2006 \mathrm{r}$. nie powiodła się).

Dojście Władimira Putina do władzy zainicjowało nowy okres w relacjach rosyjsko-białoruskich, dając prymat względom ekonomicznym, zwłaszcza zaś energetycznym. Władze rosyjskie wielokrotnie wspierały prezydenta Łukaszenkę, czyniąc wiele, aby utrzymać Białoruś w swojej strefie wpływów, zwłaszcza po zwycięstwie rewolucji w Gruzji oraz na Ukrainie. Rosja jest przy tym jednym z nielicznych państw popierających władze w Mińsku na arenie międzynarodowej i dopóki nie pojawi się alternatywa dla Aleksandra Łukaszenki, „drugiego Janukowycza”, może on liczyć na poparcie ze strony wschodniego sąsiada ${ }^{39}$. Już w 2006 r. V. Silicki zauważył, że władze Rosji nie mają możliwości współpracy na Białorusi z nikim poza Aleksandrem Łukaszenkąa ${ }^{40}$. Choć Białoruś

35 S. Huntington, Zderzenie cywilizacji, przeł. H. Jankowska, Warszawa 2006, s. 274. Należy stwierdzić, że tym, co w istocie zapobiegło pełnej integracji (a więc włączeniu Białorusi do Rosji) była i jest postawa prezydenta Łukaszenki. W pewnej mierze to jego „lawirowanie” pomiędzy Unią Europejską i Rosja pozwoliło Białorusi trwać w odrębności od dużo silniejszego sąsiada. Białoruski autorytaryzm umożliwił zarazem przetrwanie modelu ekonomicznego i społecznego państwa, konserwując archaiczne formy gospodarowania.

${ }^{36}$ A. Staszczyk, Rosja w relacjach $z$ otoczeniem, [w:] Rosja między imperium..., s. 260. Jak stwierdził Miłosz Papla, „droga do odbudowy imperium w Europie Środkowej i Wschodniej, a także do obrony przed wpływami zewnętrznymi prowadziła właśnie przez Białoruś, dlatego można nazwać tereny tego państwa »sworzniem geopolitycznym « Europy Środkowej i Wschodnie j”. M. Papla, Białoruś: protektorat Rosji, pogranicze Europy czy sworzeń geopolityczny Europy Środkowo-Wschodniej, [w:] Polityka zagraniczna Federacji Rosyjskiej. Wybrane aspekty stosunków z Polską, Ukraina i Białorusią, red. L. Zyblikiewicz, M. Czajkowski, P. Bajor, Kraków 2010, s. 242.

37 A. Eberhardt, Gra pozorów. Stosunki rosyjsko-białoruskie 1991-2008, Warszawa 2008, s. 133.

38 Zdaniem K. Kłysińskiego i P. Żochowskiego „kluczowy wpływ na zmianę rosyjskiej perspektywy miały wydarzenia na Ukrainie, które zwiększyły nieufność Moskwy do wszelkich przejawów samodzielności władz tych republik postsowieckich, które wciąż pozostają w sojuszniczych stosunkach z Rosją i dodatkowo są od niej uzależnione gospodarczo i energetycznie. Białoruś dotąd była prezentowana jako modelowy przykład tego rodzaju bliskich relacji”. K. Kłysiński, P. Żochowski, Koniec mitu bratniej Białorusi. Uwarunkowania i przejawy rosyjskiego soft power na Białorusi po 2014 roku, Warszawa 2016, s. 6.

${ }^{39}$ Krystyna Plebańska: Białoruś - punkt dla Rosji?, Psz.pl: Bliska zagranica w kolorach tęczy, Portal Spraw Zagranicznych, http://www.psz.pl/117-polityka/psz-pl-bliska-zagranica-w-kolorach-teczy (dostęp: 12 lutego 2017).

40 Białoruś jako geopolityczny parias, [w:] Geopolityczne miejsce Białorusi w Europie i świecie, red. V. Bulhakau, Warszawa 2006, s. 104. Jak stwierdził V. Silicki, Rosja może przy tym obalić prezydenta Łukaszenkę tylko przy pomocy nacisku gospodarczego, a nie wpływu politycznego. Stopień zaś tego nacisku może być taki, że spowoduje niekontrolowane następstwa, gdy Rosja nie będzie mogła kontrolować upadku reżimu. Ibidem. 
jest $\mathrm{w}$ dużym stopniu zależna od współpracy $\mathrm{z}$ Rosją oraz angażuje się w integracyjne inicjatywy wysuwane przez FR (bliskość współpracy jest szczególnie widoczna w sferze wojskowej), to stara się jednak normalizować stosunki z UE czy Radą Europy.

Zgodzić się zatem należy z Konradem Świdrem, że białoruskie społeczeństwo jest „Zakładnikiem” stosunków geopolitycznych pomiędzy Zachodem i Rosją, ponieważ to ich charakter determinuje trwałość rządów prezydenta Łukaszenki. Jednocześnie jednak z uwagi na napięcia w relacjach tak z Zachodem, jak i ze Wschodem białoruskie władze próbują znaleźć „trzecią drogę”. Częste taktyczne zwroty ku Zachodowi (a zwłaszcza UE) można uznać za próbę balansu. Ponadto ocieplanie relacji z UE jest zwykle ściśle kontrolowane i odbywa się z zachowaniem możliwości manewru, aby białoruskie władze mogły osiągnąć lepszą pozycję negocjacyjną w stosunkach $z$ Rosją ${ }^{41}$. Dlatego też niewykluczone, że po stłumieniu marcowych protestów społecznych i spodziewanym kolejnym już ochłodzeniu relacji na linii UE-Białoruś nastąpią kolejne przejawy poprawy stosunków białorusko-rosyjskich. Wraz jednak z coraz większymi wpływami Rosji w białoruskiej gospodarce pole manewru władz w Mińsku będzie się stopniowo kurczyć. Obawy przed możliwą rosyjską ekspansją (przy okazji manewrów wojskowych) są dowodem na obecny charakter relacji w tym zawartym jeszcze w połowie lat dziewięćdziesiątych „małżeństwie z rozsądku”.

\section{Podsumowanie}

Kolejna już polityczna wolta dokonana przez białoruskie władze wpisuje się w koncepcję wielowektorowości, której hołdują władze w Mińsku. Należy stwierdzić, że tym, co może w trwalszy sposób złączyć Białoruś z Zachodem, jest rozwój współpracy o charakterze gospodarczym. Problemy związane z lekceważeniem zasad demokracji i łamaniem praw człowieka nie powinny pociągać za sobą zrywania współpracy przede wszystkim z tego względu, że izolowana Białoruś skazana jest na współpracę z Rosją. Dużą rolę ma do odegrania Polska niemająca względem swojego sąsiada żadnych historycznych uprzedzeń, a mogąca wesprzeć go poprzez inwestycje w słabnącą białoruską gospodarkę. Po brutalnym stłumieniu protestów opozycji w marcu 2017 r. zbliżenie UE z Białorusią jest jednak trudniejsze.

Współpraca pomiędzy Unią Europejską i Białorusią może przebiegać na bardzo wielu płaszczyznach. Co najważniejsze, państwa Zachodu powinny zintensyfikować gospodarczą kooperację z Białorusią, co pozwoli stworzyć realną alternatywę wobec wsparcia płynącego ze strony słabnącej gospodarczo Rosji. Należy mieć przy tym świadomość, że „wyłuskanie” Białorusi z rosyjskiej strefy wpływów jest jednak trudnym zadaniem. Specyfika autorytarnie rządzonej Białorusi sprawia, że współpraca UE z tym państwem w przewidywalnej przyszłości nie będzie pełna. Ograniczać ją też będzie strategiczne

${ }^{41}$ K. Świder, Rosyjska świadomość geopolityczna a Ukraina i Białoruś (po rozpadzie Związku Radzieckiego), Warszawa 2015, s. 294. 
(głównie w sferze gospodarczej) partnerstwo łączące Rosję z Niemcami będącymi najbardziej wpływowym członkiem Unii Europejskiej.

W kontekście pierwszej z hipotez należy stwierdzić, że aktywność UE względem Białorusi nie przynosi sukcesów, ponieważ przeszkadza temu w szczególności wewnętrzna polityka prezydenta Łukaszenki względem opozycji, lecz także łamanie zasad demokracji, co jest sprzeczne z zasadami wyznawanymi przez tę organizację. Niedocenianym często argumentem, przemawiającym za takim wyborem politycznej drogi, jest obawa prezydenta Łukaszenki o osłabienie jego władzy, co nastąpiłoby, gdyby idąc za wskazaniami UE, zdecydował się na demokratyczne reformy i „złagodził kurs” wobec opozycji. Z uwagi na to dalszy kształt relacji UE-Białoruś wciąż zależny będzie od woli prezydenta Łukaszenki znajdującego się pod coraz większą presją władz w Rosji zainteresowanych osłabieniem stosunków jej sąsiada z Zachodem.

Polityka Unii Europejskiej zmierza ku nawiązaniu możliwie ścisłej współpracy z Białorusią, choć przy respektowaniu stanowiska władz w Moskwie. Sama UE jest jednak świadoma istniejących ograniczeń wynikających z silnych powiązań pomiędzy Białorusią i Rosją, które uniemożliwiają większą swobodę i efektywność działań. Obszary współpracy są jednak liczne i różnorodne, czego wyrazem jest między innymi aktywność w ramach Partnerstwa Wschodniego. Szczególnie aktywna jest polityka polskich władz wobec Białorusi. Polska jest dla Białorusi jednym z najbliższych państw Zachodu, a zarazem głównym zainteresowanym współpracą rozwojową w ramach Partnerstwa Wschodniego, w którym partycypuje między innymi Białoruś.

Pogorszenie się relacji białorusko-rosyjskich niewątpliwie otworzyło pewne szanse w stosunkach UE z Białorusią. Perspektywy unijnej polityki prowadzonej wobec tego państwa w dużej mierze zależą od stanowiska władz Rosji. Sama Białoruś, od lat zmagająca się z problemami gospodarczymi, jest zainteresowana głównie otrzymaniem wsparcia gospodarczego. Jednocześnie w przewidywalnej przyszłości nie dojdzie tam do radykalnej zmiany kursu w kwestii przestrzegania zasad demokracji, na czym zależy UE, jak i do fundamentalnych reform ekonomicznych. Prezydent Łukaszenka, który jest niewątpliwie bardzo skutecznym taktykiem, zdaje sobie sprawę z tego, że UE może znów „zamrozić” współpracę z Białorusią, jeśli w państwie nie będą przestrzegane zasady demokracji i nasilą się represje wobec przeciwników władz w Mińsku.

Odnosząc się zatem do drugiej hipotezy, należy ponownie podkreślić, że Białoruś jest w obecnej sytuacji zależna od Rosji, co przede wszystkim znajduje swój wyraz w sferze gospodarczej. Rosyjskie władze mogą mieć poważny wpływ na kształt relacji UE-Białoruś, a współpraca ze wschodnim sąsiadem jest jednak przez prezydenta Łukaszenkę traktowana priorytetowo. Dla rosyjskich władz najważniejszą rolę odgrywa tranzytowe znaczenie Białorusi, istotne ze względów geostrategicznych i geoekonomicznych. Proces integracyjny, który od połowy lat dziewięćdziesiątych XX w. dokonuje się między Białorusią i Rosją, można uznać za istotny krok na drodze do odtworzenia przez władze w Moskwie strefy wpływów istniejącej w czasach ZSRR. Dlatego też relacje łączące UE i Białoruś są postrzegane przez władze w Rosji jako zagrożenie jej wpływów w tym państwie. 
Warto zauważyć, że choć Białoruś utrzymała wiele przedsiębiorstw w rękach państwa, to jednak podmioty związane z Rosją od lat wykupują majątek państwowy jej zachodniego sąsiada. Na tym tle ewentualny udział polskich przedsiębiorstw w prywatyzacji na Białorusi należy postrzegać jako ważny krok na drodze do (choćby nawet znów tylko czasowego) zwrotu tego państwa ku Zachodowi. Unijne (a więc i polskie) zaangażowanie w przemiany na Białorusi stanowi szansę, na której drodze stoi zresztą nie tylko neoimperialna polityka rosyjskich władz, lecz także wewnętrzna sytuacja państwa, w którym zachowanych zostało jeszcze wiele reliktów z czasów ZSRR, jak na przykład istnienie gospodarki planowej. Kolejna już rozprawa z politycznymi przeciwnikami, która miała miejsce w marcu 2017 r., może oddalić w czasie ewentualne realne zbliżenie UE i Białorusi, na czym zyska przede wszystkim Rosja.

\section{Bibliografia}

Białoruś jako geopolityczny parias, [w:] Geopolityczne miejsce Białorusi w Europie i świecie, red. V. Bulhakau, Wyższa Szkoła Handlu i Prawa im. Ryszarda Łazarskiego w Warszawie, Instytut Przestrzeni Obywatelskiej i Polityki Społecznej, Warszawa 2006.

Białoruś: Mińsk otrzyma od UE 7 mln euro na nielegalnych migrantów, „Rzeczpospolita”, 17 stycznia 2017 , http://www.rp.pl/Uchodzcy/170119149-Bialorus-Minsk-otrzyma-od-UE-7-mln-euro-na-nielegalnych-migrantow.html\#ap-1.

Czachor R., Polityka wielowektorowości Republiki Białoruś: geneza, podstawy konceptualne, przykłady realizacji, „Wrocławski Przegląd Międzynarodowy” 2011, nr 1.

Czachor R., Polityka zagraniczna Republiki Białoruś w latach 1991-2011: studium politologiczne, Dolnośląska Wyższa Szkoła Przedsiębiorczości i Techniki, Polkowice 2011.

Dudek A., Koncepcje polskiej polityki wschodniej po rozszerzeniu Unii Europejskiej, [w:] Rosja między imperium a mocarstwem kolonialnym, red. A. Dudek, R. Mazur, Wydawnictwo Adam Marszałek, Toruń 2010.

Eberhardt A., Gra pozorów. Stosunki rosyjsko-białoruskie 1991-2008, Polski Instytut Spraw Międzynarodowych, Warszawa 2008.

Eberhardt A., Republika Białoruś a współpraca i integracja w Europie - przyczyny $i$ konsekwencje izolacji międzynarodowej, [w:] Polska i Białoruś po rozszerzeniu Unii Europejskiej, red. M. Krzysztofowicz, Polski Instytut Spraw Międzynarodowych, Warszawa 2005.

Fiszer J.M., Białoruś między Rosją i Unią Europejską - konflikty interesów i perspektywy współpracy, [w:] Białoruś między Unią Europejską a Rosją, red. A. Kantorowicz, Wydawnictwo Akademii Finansów i Biznesu Vistula, Warszawa 2012.

Gieorgica J.P., Białoruś - między Polską a Rosją — konflikt czy dialog, [w:] Białoruś między Unią Europejską a Rosją, red. A. Kantorowicz, Warszawa 2012.

Guicherd C., The EU and Belarus: From a Zero to a Positive Sum Game, [w:] The EU \& Belarus: between Moscow \& Brussels, red. A. Lewis, London 2002.

Huntington S., Zderzenie cywilizacji, przeł. H. Jankowska, Wydawnictwo MUZA S.A., Warszawa 2006.

Iwańczuk K., Pozycja geopolityczna Białorusi, [w:] Białoruś w stosunkach międzynarodowych, red. I. Topolski, Wydawnictwo UMCS, Lublin 2009.

Jak rozmawiać z Białorusią? Prof. Kazimierz Kik dla Fronda.pl, Fronda.pl, 5 listopada 2016 r., http://www. fronda.pl/a/jak-rozmawiac-z-bialorusia-prof-kazimierz-kik-dla-frondapl,81283.html.

Kłysiński K., Żochowski P., Koniec mitu bratniej Białorusi. Uwarunkowania i przejawy rosyjskiego soft power na Białorusi po 2014 roku, Warszawa 2016.

Krystyna Plebańska: Białoruś - punkt dla Rosji?, Psz.pl: Bliska zagranica w kolorach tęczy, Portal Spraw Zagranicznych, http://www.psz.pl/117-polityka/psz-pl-bliska-zagranica-w-kolorach-teczy. 
Mączka M., Geopolityka i geostrategia Białorusi w świecie - jak widzi i kształtuje ją Mińsk?, [w:] Białoruś - terra incognita. Materiały z konferencji, red. M. Smoleń, Wydawnictwo Uniwersytetu Jagiellońskiego, Kraków 2010.

Mironowicz E., Unia Europejska w polityce białoruskiej 2008-2010, [w:] Białoruś między Uniq Europejska a Rosja, red. A. Kantorowicz, Warszawa 2012.

Młynarska K., Pałka K., Białoruś - między Rosją a Europą. Kierunki polityki zagranicznej Białorusi w okresie prezydentury Aleksandra Łukaszenki, [w:] Wschód i Zachód w wymiarze globalnym. Doświadczenia z przeszłości a perspektywy na przyszłość, red. M. Miłek, G. Wilk-Jakubowski, R.S. Brzoza, Kielce 2012.

Papla M., Białoruś: protektorat Rosji, pogranicze Europy czy sworzeń geopolityczny Europy Środkowo-Wschodniej, [w:] Polityka zagraniczna Federacji Rosyjskiej. Wybrane aspekty stosunków z Polską, Ukraina i Białorusia, red. L. Zyblikiewicz, M. Czajkowski, P. Bajor, Wydawnictwo Uniwersytetu Jagiellońskiego, Kraków 2010.

Partnerstwo Wschodnie, Ministerstwo Spraw Zagranicznych, http://www.msz.gov.pl/pl/polityka_zagraniczna/partnerstwo_wschodnie.

Polsko-białoruskie rozmowy w Warszawie, Ministerstwo Spraw Zagranicznych, 19 lipca 2016 r., http:// www.msz.gov.pl/pl/polityka_zagraniczna/partnerstwo_wschodnie/polsko_bialoruskie_rozmowy_w_ warszawie_pw;jsessionid=1679F7E53E66EBF2AA7383F2D030EB07.cmsap2p.

Staszczyk A., Rosja $w$ relacjach $z$ otoczeniem, [w:] Rosja między imperium a mocarstwem kolonialnym, red. A. Dudek, R. Mazur, Toruń 2010.

Świder K., Rosyjska świadomość geopolityczna a Ukraina i Białoruś (po rozpadzie Związku Radzieckiego), Instytut Studiów Politycznych PAN, Warszawa 2015.

UE chce podpisać stowarzyszenie z Białorusia, Sputniknews.com, 28 listopada 2016 r., https://pl.sputniknews. com/polityka/201611284308704-ue-bialorus-porozumienie.

Zagorski A., EU Policies Towards Russia, Ukraine, Moldova and Belarus, „Occasional Paper Series” 2005, nr 35, https://www.files.ethz.ch/isn/10671/doc_10702_290_en.pdf. Zięba R., Główne kierunki polityki zagranicznej Polski po zimnej wojnie, Warszawa 2010.

Ланг К.-О., Коопманн М., ЕС и Беларусь: отношения с резервными возможностями, [w:] Беларусь и Европейский союз: от изоляции к сотрудничеству, red. Х.-Г. Вик, Ш. Малериус, Вильнюс 2011.

Об утверждении Основных направлений внутренней и внешней политики Республики Беларусь, 14 ноября 2005 г. № 60-3, http://pravo.by/document/?guid=3871\&p0=H10500060.

Русакович А., Беларусь - Европейский союз: основные проблемы партнерства, [w:] Актуальныя пьтанні беларуска-польскіх адносін: да 20-годдзя Дагавора паміж Рэспублікай Беларусь і Рэспублікай Польшча аб добрасуседстве, сяброўстве і супраиоўніитве ад 23 чэрвеня 1992 г.: матэрыялы беларус.-пол. круглага стала, red. В.Г. Шадурскі, Мінск 2012.

Силицкий В., Беларусь в международном контексте, [w:] Беларусь и Европейский союз: от изоляции $\kappa$ сотрудничеству, red. Х.-Г. Вик, Ш. Малериус, Вильнюс 2011.

Снапковский В.Е., История внешней политики Беларуси: пособие [для студентов по специальностям «Международные отношения», «Лингвострановедение», «Международная журналистика], Минск 2013.

Указ Президента Республики Беларусь от 9 ноября 2010 г. N575 “Об утверждении Концепции национальной безопасности Республики Беларусь”, Комитет государственной безопасности Республики Беларусь, http://kgb.by/ru/ukaz575.

Улахович В., Формирование основ внешней политики Республики Беларусь, Минск 2009.

Чубрик А., Текущее положение дел и перспективы сотрудничества с ЕС: социально-экономический и инфраструктурный аспекты, [w:] Беларусь и Европейский союз: от изоляции к сотрудничеству, red. Х.-Г. Вик, Ш. Малериус, Вильнюс 2011. 


\section{Between chances and barriers. Current problems of cooperation between the European Union and Belarus}

Keywords: chance, cooperation, EU, Belarus

Summary

The article shows the complexity of the relationship between the European Union and Belarus. Despite efforts of the EU diplomacy these relations have faced a number of problems since years. Currently, they entered into a new phase, which raises hope for a closer cooperation. The author shows the importance of the relationship between Belarus and Russia, development of EU relations over the past years and the role of the Eastern Partnership and Poland as a country particularly interested in developing cooperation with Belarus. The author presents the areas of cooperation with Belarus, in particular he focuses on the economic aspect of the cooperation. Even though the relationship between the EU and Belarus currently develops it is not clear if this will continue in the future. 